\title{
APLIKASI ANALISIS JALUR DALAM PENENTUAN PENGARUH KUALITAS TANAH DAN AIR TERHADAP PRODUKSI TOTAL TAMBAK DI KABUPATEN DEMAK, PROVINSI JAWA TENGAH
}

\author{
PATH ANALYSIS APPLICATION IN DETERMINING THE EFFECT OF SOIL AND WATER \\ QUALITYON TOTAL PRODUCTION OF BRACKISHWATER PONDS IN \\ DEMAK REGENCY, CENTRAL JAVA PROVINCE
}

\author{
Akhmad Mustafa dan Admi Athirah \\ Balai Penelitian dan Pengembangan Budidaya Air Payau \\ Jalan Makmur Daeng Sitakka 129 Maros 90512, Sulawesi Selatan \\ E-mail: akhmadmustafa@yahoo.com
}

Diterima tanggal: 4 Mei 2014, diterima setelah perbaikan: 7 Juli 2014, disetujui tanggal: 17 Juli 2014

\begin{abstract}
ABSTRAK
Kualitas tanah dan air tambak adalah faktor yang sangat menentukan produktivitas tambak termasuk produksi total (udang windu dan ikan bandeng) di Kabupaten Demak, Provinsi Jawa Tengah. Namun demikian, belum ada informasi mengenai pengaruh kualitas tanah dan air terhadap produksi total di tambak Kabupaten Demak. Oleh karena itu dilakukan penelitian yang bertujuan untuk mengetahui pengaruh langsung atau tidak langsung kualitas tanah dan air terhadap produksi total di tambak Kabupaten Demak. Penelitian dilaksanakan di kawasan tambak Kecamatan Karangtengah dan Sayung, Kabupaten Demak. Kualitas tanah ditetapkan sebagai variabel independen dan eksogen; kualitas air sebagai variabel perantara, dependen dan endogen; serta produksi total sebagai variable dependen dan endogen. Karakteristik kualitas tanah dan air serta produksi total diketahui melalui aplikasi statistik deskriptif, sedangkan pengaruh kualitas tanah dan air terhadap produksi total diketahui melalui aplikasi analisis jalur. Hasil penelitian menunjukkan bahwa dari 14 variabel kualitas tanah yang dianalisis dengan analisis jalur ternyata hanya 2 variabel yang mempengaruhi produksi total yaitu: kandungan bahan organikdan fosfat, sedangkan dari 7 variabel kualitas air, ternyata ada 3 variabel yang mempengaruhi produksi total tambak yaitu kandungan fosfat, salinitas dan nitrat. Kandungan bahan organik tanah berpengaruh sangat nyata dengan pengaruh langsung sebesar 0,404 terhadap produksi total, sedangkan fosfat tanah berpengaruh nyata dengan pengaruh langsung sebesar 0,267 terhadap produksi total. Kandungan fosfat, salinitas dan nitrat air berpengaruh terhadap produksi total dengan pengaruh langsung masingmasing $0,117,-0,414$ dan 0,377 terhadap produksi total. Kedua variabel kualitas tanah tersebut juga memiliki pengaruh tidak langsung terhadap produksi total tambak melalui pengaruhnya terhadap fosfat, salinitas dan nitrat air. Aplikasi pupuk organik dan pupuk anorganik yang mengandung fosfat pada tanah serta aplikasi pupuk anorganik yang mengandung fosfat dan nitrogen pada air serta penurunan salinitas air diharapkan dapat meningkatkan produktivitas tambak di Kabupaten Demak.
\end{abstract}

Kata kunci: analisis jalur, tanah, air, tambak, Kabupaten Demak

\section{ABSTRACT}

Soil and water quality are the factors that determine brackishwater ponds productivity including the total production (tiger shrimp and milkfish) in Demak Regency, Central Java Province. However, there is no information on the effect of soil and water quality on the total production in brackishwater ponds of Demak Regency. Therefore, research aimed to determine direct effect and indirect effect of soil and water quality on total production of brackishwater ponds in Demak Regency. The research was conducted in brackishwater ponds of Karangtengah and Sayung Subdistricts, Demak Regency. Soil quality was defined as independent and exogenous variables; water quality as an intermediate, dependent and endogenous variables; and total production as dependent and endogenous variables. Characteristics of soil and water quality as well as the total production is known through descriptive statistics application, while the effect of soil and water quality on total production is known through path analysis applications. The results of path analysis showed that 14 soil quality variables analyzed was only 2 variables that affect on total production, namely: organic matter and phosphate, and 7 water quality variables analysed only 3 variables that affect on total production namely:

Aplikasi Analisis Jalur dalam Penentuan Pengaruh Kualitas Tanah dan Air Terhadap Produksi Total Tambak di Kabupaten Demak, Provinsi Jawa Tengah - Akhmad Mustafa dan Admi Athirah 
phosphate, salinity and nitrate. Soil organic matter was highly significant with a direct effect of 0.404 on the total production, while soil phosphate was significant with a direct effect of 0.267 on total production. Water phosphate, salinity and nitrate affect on total production with the direct effects of $0.117,-0.414$, and 0.377, respectively. Both the soil quality variables also have an indirect effect on total production through its influence on water phosphate, salinity and nitrate. Application of organic fertilizer and inorganic fertilizers containing phosphates to the soil and inorganic fertilizers application containing phosphate and nitrogen in the water as well as a decrease in the salinity of the water is expected to increase brackish water ponds productivity in Demak.

Keywords: path analysis, soil, water, brackishwater pond, Demak Regency

\section{PENDAHULUAN}

Demak merupakan salah satu kabupaten di Provinsi Jawa Tengah yang memiliki panjang garis pantai $72,14 \mathrm{~km}$, sehingga memiliki potensi perikanan tangkap maupun perikanan budidaya (akuakultur) terutama budidaya tambak (budidaya air payau). Budidaya tambak di Kabupaten Demak tersebar di empat kecamatan yaitu Kecamatan Karangtengah, Sayung, Bonang dan Wedung dengan luas total 7.945,97 ha (Anonim, 2011). Kabupaten Demak sesuai dengan Keputusan Menteri Kelautan dan Perikanan Indonesia Nomor KEP.32/MEN/2010 tentang Penetapan Kawasan Minapolitan telah ditetapkan sebagai kawasan minapolitan bersama 13 kabupaten/kota di Provinsi Jawa Tengah. Keputusan Direktur Jenderal Perikanan Budidaya Nomor Kep.240/DJ-PB/2012 tentang Penetapan 87 Lokasi Sentra Produksi Perikanan Budidaya sebagai Kawasan Minapolitan Percontohan tahun 2013 telah menetapkan bahwa Kabupaten Demak sebagai lokasi kawasan minapolitan percontohan. Kementerian Kelautan dan Perikanan juga telah menetapkan program industrialisasi budidaya tambak untuk udang dan ikan bandeng di beberapa kabupaten di Provinsi Jawa Tengah, termasuk Kabupaten Demak. Perjanjian Kerja Sama antara Direktorat Jenderal Perikanan Budidaya dengan Pemerintah Kabupaten Demak Nomor 2553/DPB/HK.320.D2/V/2012 dan Nomor 523/147/2012 tentang Revitalisasi Tambak untuk mencapai industrialisasi udang tahun 20122014 menetapkan Kabupaten Demak sebagai lokasi revitalisasi tambak.

Secara umum, kualitas tanah dan air adalah faktor penentu dominan dalam budidaya tambak, sehingga dipertimbangkan sebagai kriteria dalam evaluasi kesesuaian lahan untuk budidaya tambak (Boyd, 1995; Treece, 2000; Salam, Ross \& Beveridge, 2003; Karthik, Suri, Saharan \& Biradar, 2005; Mustafa et al., 2007; Hardjowigeno dan Widiatmaka, 2011; Mustafa, 2012). Kualitas tanah dan air tambak adalah faktor penting yang mempengaruhi produksi di tambak (Mustafa dan Ratnawati, 2005; Mustafa dan Sammut, 2007). Meskipun pengelolaan kualitas air dianggap salah satu faktor budidaya paling penting, tetapi banyak bukti bahwa kondisi dasar tambak dan pertukaran substansi antara tanah dan air sangat berpengaruh terhadap kualitas air (Boyd, 1995; Boyd, Wood, \& Thunjai, 2002). Kualitas tanah dasar tambak dan proses yang terjadi pada tanah dasar tambak serta hubungan tanah dan air tambak menjadi sangat penting bagi pertumbuhan udang atau ikan di tambak (Avnimelech dan Ritvo, 2003). Dalam tanah tambak dapat terjadi proses kimia, fisika dan biologi oleh organisme akuatik dan mikroorganisme yang dapat mengubah unsur hara dalam tanah yang akan mempengaruhi kualitas air yang ada di atasnya (Boyd, 1992). Kualitas air tambak dipengaruhi oleh kesuburan tanah tambaknya (Ndome, Udo, Akpan \& Udom, 2012). Permasalahan kualitas air dalam tambak seringkali dapat bermula dari kualitas tanah, seperti rendahnya $\mathrm{pH}$ dan alkalinitas air pada tanah masam, rendahnya kandungan oksigen terlarut sebagai akibat banyaknya oksigen yang dibutuhkan untuk dekomposisi bahan organik dalam tanah dan adanya senyawa tereduksi seperti nitrit $\left(\mathrm{NO}_{2}\right)$, hidrogen sulfida $\left(\mathrm{H}_{2} \mathrm{~S}\right)$, besi $(\mathrm{Fe})$ dan mangan $(\mathrm{Mn})$ yang diproduksi oleh mikroorganisme pada tanah yang anaerob. Namun demikian, belum ada informasi rinci mengenai hubungan sebab akibat dari kualitas tanah dan atau kualitas air dalam mempengaruhi produksi tambak di Kabupaten Demak.

Analisis jalur (path analysis) adalah suatu teknik untuk menganalisis hubungan sebab akibat yang terjadi pada regresi berganda apabila variabel independennya mempengaruhi variabel dependen, tidak hanya secara langsung, tetapi juga secara tidak langsung (Rutherford dan Choe, 1993; Everitt dan Dunn, 2001). Analisis jalur atau analisis lintas atau analisis lintasan merupakan 
pengembangan langsung bentuk regresi berganda dengan tujuan untuk memberikan estimasi tingkat kepentingan dan signifikansi hubungan sebab akibat hipotetikal dalam seperangkat variabel (Streiner, 2005; Sarwono, 2007). Sesuai dengan hakikatnya, analisis jalur bukan difungsikan untuk mencari faktor penyebab, tetapi hanya membuat model kausal yang dapat digunakan untuk membuat penjelasan teoritis (Amir, 2006). Analisis jalur telah digunakan oleh Mustafa dan Ratnawati (2013) yang hasilnya menunjukkan bahwa variabel kualitas tanah berupa $\mathrm{pH}_{\mathrm{FOX}}(\mathrm{pH}$ tanah yang diukur di lapangan setelah dioksidasi dengan hidrogen peroksida $\left(\mathrm{H}_{2} \mathrm{O}_{2}\right)$ 30\%) dan potensial redoks tanah serta variabel kualitas air berupa padatan tersuspensi total, $\mathrm{pH}$ dan potensial redoks mempengaruhi produksi ikan bandeng di tambak tanah sulfat masam Klaster Tinanggea, Kabupaten Konawe Selatan, Provinsi Sulawesi Tenggara. Athirah, Asaf, dan Ratnawati (2013) juga telah mengaplikasikan analisis jalur yang hasilnya menunjukkan bahwa kualitas tanah seperti potensial redoks dan $\mathrm{pH}_{\mathrm{F}}(\mathrm{pH}$ tanah yang diukur langsung di lapangan) tanah serta variabel kualitas air seperti padatan tersuspensi total, bahan organik total dan besi mempengaruhi produktivitas tambak di Kabupaten Indramayu, Provinsi Jawa Barat. Oleh karena itu dilakukan penelitian yang bertujuan untuk mengkarakteristik tanah dan air tambak serta menganalisis hubungan kausal antar variabel kualitas tanah dan kualitas air dan produksi tambak dengan tujuan untuk mengetahui pengaruh langsung atau tidak langsung kualitas tanah dan air terhadap produksi tambak di Kabupaten Demak melalui aplikasi analisis jalur.

\section{BAHAN DAN METODE}

\subsection{Waktu dan Lokasi Penelitian}

Penelitian awal dimulai berupa pertemuan dengan staf Dinas Kelautan dan Perikanan Kabupaten Demak di Demak pada bulan Februari 2013. Penelitian inti berupa pengambilan contoh tanah dan air serta wawancara dengan responden dilaksanakan pada bulan Juni dan Juli 2013 di Kecamatan Karangtengah dan Sayung, Kabupaten Demak, Provinsi Jawa Tengah. Analisis kualitas tanah dan air masing-masing dilaksanakan di Laboratorium Tanah dan Laboratorium Air, Balai Penelitian dan Pengembangan Budidaya Air Payau, Kabupaten Maros, Provinsi Sulawesi Selatan.

\subsection{Pengumpulan Data}

Metode survei diaplikasikan dalam penelitian ini. Pengambilan contoh yang bertujuan (purposive sampling) digunakan dalam survei. Data yang dikumpulkan meliputi kualitas tanah dan kualitas air serta produksi total tambak. Penentuan titiktitik pengambilan contoh didasarkan pada peta Satuan Unit (Gambar 1). Pengukuran dan pengambilan contoh tanah dilakukan pada kedalaman 0-0,2 m. Kualitas tanah yang diukur langsung di lapangan adalah potensial redoks diukur dengan redox-meter, $\mathrm{pH}_{\mathrm{F}}(\mathrm{pH}$ tanah yang diukur langsung di lapangan) dengan $\mathrm{pH}$-meter dan $\mathrm{pH}_{\mathrm{FOX}}(\mathrm{pH}$ tanah yang diukur di lapangan setelah dioksidasi dengan hidrogen peroksida $\left.\left(\mathrm{H}_{2} \mathrm{O}_{2}\right) 30 \%\right)$ dengan $\mathrm{pH}$-meter mengikuti petunjuk Ahern, Blunden, Sullivan \& McElnea (2004). Contoh tanah juga diambil untuk analisis variabel kualitas tanah lainnya di laboratorium. Contoh tanah dikeringanginkan dalam ruangan khusus bebas kontaminan yang terlindung dari sinar matahari. Setelah kering, contoh tanah dihaluskan dengan cara ditumbuk pada lumpang porselin dan diayak dengan ayakan ukuran lubang 2,0 $\mathrm{mm}$. Untuk mendapatkan partikel berukuran $0,5 \mathrm{~mm}$, maka contoh partikel berukuran 2,0 mm ditumbuk dan disaring dengan saringan $0,5 \mathrm{~mm}$. Kualitas tanah yang dianalisis di laboratorium meliputi $\mathrm{pH}_{\mathrm{H} 2 \mathrm{O}}\left(\mathrm{pH}\right.$ dengan pengekstrak $\left.\mathrm{H}_{2} \mathrm{O}\right), \mathrm{pH}_{\mathrm{KCl}}(\mathrm{pH}$ tanah dengan pengekstrak $\mathrm{KCl}$ ), bahan organik dari karbon organik (C-organik) dengan metode Walkley dan Black, nitrogen total ( $\mathrm{N}$ total) dengan metode Kjedhal dan ortofosfat $\left(\mathrm{PO}_{4}\right)$ dengan metode Bray 1 mengikuti petunjuk Eviati dan Sulaeman (2009), besi (Fe) dan aluminium (Al) dengan spektrofotometer mengikuti petunjuk Menon (1973) dan tekstur dengan metode hidrometer mengikuti petunjuk Agus, Yusrial \& Sutono (2006).

Pengukuran dan pengambilan contoh air di tambak mengikuti titik pengambilan contoh tanah. Variabel kualitas air yang diukur langsung di lapangan adalah salinitas dan $\mathrm{pH}$ dengan menggunakan Hydrolab® Minisonde. Contoh air untuk dianalisis di laboratorium diambil dengan menggunakan Kemerer Water Sampler dan dipreservasi mengikuti petunjuk APHA (2005). Variabel kualitas air yang dianalisis di laboratorium meliputi: nitrat $\left(\mathrm{NO}_{3}\right)$ (metode reduksi kadmium), $\mathrm{NO}_{2}$ (metode kolorimetri), amonia $\left(\mathrm{NH}_{3}\right)$ (metode fenat), ortofosfat $\left(\mathrm{PO}_{4}\right)$ (metode asam askorbat) dan bahan organik total 
(metode basa) mengikuti petunjuk Strickland dan Parsons (1972), Menon (1973), Grasshoff (1976), Parsons, Maita \& Lalli (1989), APHA (2005) serta Sutrisyani dan Rohani (2009).

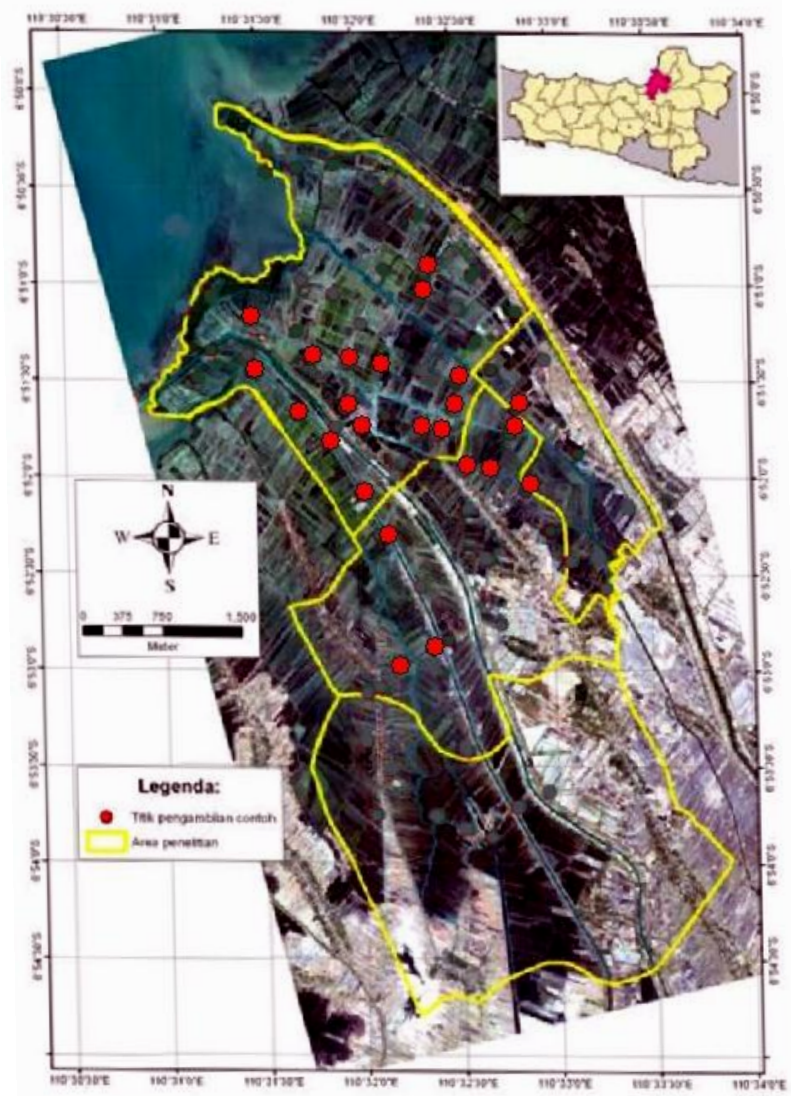

Gambar 1. Peta titik-titik pengambilan contoh di tambak Kecamatan Karangtengah dan Sayung, Kabupaten Demak

Figure 1. Map of example spots that taked in " Tambak' in Karang Tengah and Sayung, Demak, Central Java Sumber: Google earth

Produksi total tambak merupakan produksi total dari udang windu (Penaeus monodon) dan ikan bandeng (Chanos chanos) (Hanafi, 1990; Mustafa dan Ratnawati, 2007), sebab tambak yang dipilih semuanya melakukan budidaya secara polikultur antara udang windu dan ikan bandeng. Data produksi tambak diperoleh melalui wawancara dengan mengajukan kuesioner secara terstruktur terhadap 24 responden. Produksi tambak yang dicatat adalah produksi 3 tahun terakhir atau 6 siklus terakhir. Responden terpilih adalah pengelola dari tambak yang diukur dan diambil contoh tanah dan contoh airnya. Global Positioning System digunakan dalam menentukan posisi kooordinat titik-titik pengambilan contoh.

\subsection{Analisis Data}

Statistik deskriptif berupa nilai minimum, maksimum, rata-rata dan deviasi standar digunakan untuk analisis data setiap variabel kualitas tanah dan air serta produksi total tambak. Uji reliabilitas dan uji validitas dilakukan terhadap data yang diperoleh dari kuesioner yaitu produksi total. Dalam analisis jalur diterapkan model mediasi di mana variabel kualitas air (sebagai variabel perantara, dependen dan endogen) memodifikasi pengaruh variabel kualitas tanah (sebagai variabel independen dan eksogen) terhadap produksi total tambak (sebagai variabel dependen dan endogen), model rekursif di mana semua anak panah menuju satu arah dan model persamaan dua jalur di mana variabel kualitas tanah sebagai variabel independen serta variabel kualitas air dan produksi total tambak sebagai variabel dependen.

Koefisien korelasi ditentukan untuk mendeteksi adanya gejala multikolinearitas. Untuk menghitung persamaan regresinya digunakan metode langkah mundur (backward) (Draper dan Smith, 1981). Koefisien korelasi kembali digunakan untuk mengetahui korelasi antarvariable eksogen terpilih dan antarvariabel perantara terpilih dan gabungan variabel eksogen dan perantara. Uji $\mathrm{R}^{2}$ (koefisien determinasi yang disesuaikan) digunakan untuk mengetahui besarnya variabel eksogen menjelaskan variabel perantara serta gabungan variabel eksogen dan perantara menjelaskan variabel dependen. Uji F digunakan untuk menguji adanya hubungan linier antarvariabel eksogen maupun antara variabel eksogen dan perantara. Uji t digunakan untuk mengetahui besarnya pengaruh variabel eksogen terhadap variabel perantara secara sendiri-sendiri atau parsial serta besarnya pengaruh variabel eksogen dan perantara terhadap variabel dependen secara parsial pula. Taraf signifikansi ditetapkan sebesar 0,01 dan 0,10. Seluruh analisis data menggunakan bantuan program IBM (International Business Machines) SPSS (Statistical Product and Service Solution) Statistics 20.

Besarnya pengaruh variabel lain di luar model ditentukan dengan menghitung koefisien analisis jalur yang menunjukkan error dengan menggunakan persamaan (Widarjono, 2010; Suliyanto, 2011):

$$
\mathrm{Pe}=\sqrt{1-\mathrm{R}^{2}}
$$


di mana:

Pe : koefisien analisis jalur

$\mathrm{R}^{2}$ : koefisien determinasi.

Penentuan besarnya pengaruh, baik pengaruh langsung, pengaruh tidak langsung dan pengaruh total variabel eksogen terhadap variabel endogen dihitung berdasarkan petunjuk Everitt dan Dunn (2001), Supranto (2004) dan Sarwono (2007). Diagram hasil analisis jalur dibuat dengan bantuan program AMOS (Analysis of Moment Structures) 16.0 .

\section{HASIL DAN PEMBAHASAN}

\subsection{Karakteristik Tanah dan Air serta Produksi Total Tambak}

Produktivitas tambak di Kabupaten Demak berkisar antara 300 dan $2.120 \mathrm{~kg} / \mathrm{ha} /$ siklus dengan rata-rata $1.105 \mathrm{~kg} / \mathrm{ha} /$ siklus (Tabel 1). Produksi ini merupakan produksi total yaitu produksi udang windu dan ikan bandeng yang dipolikulturkan di tambak Kabupaten Demak. Hasil yang diperoleh ini lebih tinggi daripada produksi total (udang windu dan ikan bandeng) di tambak Kabupaten Pinrang, Provinsi Sulawesi Selatan yang berkisar antara 100 dan $3.050 \mathrm{~kg} / \mathrm{ha} /$ siklus dengan rata-rata $499 \mathrm{~kg} / \mathrm{ha} / \mathrm{siklus}$ (Mustafa dan Ratnawati, 2007). Udang windu dan ikan bandeng adalah komoditas yang dapat dipolikulturkan di tambak (Ranoemihardjo, Kahar \& Lopez 1979; Eldani dan Primavera, 1981). Kedua komoditas tersebut secara umum menuntut kondisi lingkungan yang relatif sama, tetapi menempati relung ekologi yang berbeda dalam tambak. Perbedaan habitat makanan dari kedua komoditas tersebut yang menyebabkan tidak terjadi kompetisi di antaranya (Eldani dan Primavera, 1981). Konsep dasar dari polikultur adalah jika dua atau lebih spesies ikan yang cocok dipelihara secara bersama-sama akan meningkatkan produksi (Shang, 1986).

Jenis tanah yang umum dijumpai di kawasan pertambakan Kabupaten Demak adalah tanah aluvial nonsulfat masam. Rata-rata potensial redoks tanah tambak di Kabupaten Demak bernilai negatif yaitu rata-rata $-102 \mathrm{mV}$ yang menunjukkan bahwa tanah dalam kondisi tereduksi yang dapat menghasilkan senyawa yang bersifat racun bagi organisme akuatik seperti senyawa $\mathrm{H}_{2} \mathrm{~S}, \mathrm{NO}_{2}$ dan $\mathrm{NH}_{3}$. Hal ini sebagai akibat dari tambak yang seluruhnya berisi air karena digunakan untuk polikultur udang windu dan ikan bandeng, sehingga terbentuk kondisi reduksi pada tanah dasar tambak. Potensial redoks tanah yang bernilai negatif juga menunjukkan adanya penumpukan bahan organik dalam kondisi anaerob (Avnimelech dan Ritvo, 2003). Walaupun pembudidya tambak di Kabupaten Demak melakukan pengeringan dasar tambak pada saat persiapan tambak yang menyebabkan potensial redoks tanah tambak secara umum bernilai positif, tetapi karena telah mengalami penggenangan menyebabkan potensial redoks tanah bernilai negatif. Seperti dikatakan oleh Ponnamperuma (1972) bahwa potensial redoks mengalami penurunan dari $+700 \mathrm{mV}$ sampai $-300 \mathrm{mV}$ pada tanah sulfat masam yang digenangi.

Kualitas tanah tambak di Kabupaten Demak disajikan pada Tabel 1. $\mathrm{pH}_{\mathrm{F}}$ dan $\mathrm{pH}_{\mathrm{FOX}}$ tanah tambak di Kabupaten Demak rata-rata 6,84 dan 6,64. Nilai selisih antara $\mathrm{pH}_{\mathrm{F}}$ dan $\mathrm{pH}_{\mathrm{FOX}}\left(\mathrm{pH}_{\mathrm{F}}-\right.$ $\mathrm{pH}_{\mathrm{FOX}}$ ) yang rendah ini yaitu rata-rata 0,42 unit menunjukkan bahwa tanah tambak di Kabupaten Demak tidak memiliki potensi kemasaman yang tinggi. Nilai $\mathrm{pH}_{\mathrm{F}}-\mathrm{pH}_{\mathrm{FOX}}$ mencapai rata-rata 3,08 unit di tambak tanah sulfat masam Kabupaten Pohuwato, Provinsi Gorontalo (Mustafa, Hasnawi, Athirah, Sommeng \& Ali, 2014); 5,59 unit di tambak tanah sulfat masam Kecamatan Malangke, Kabupaten Luwu Timur, Provinsi Sulawesi Selatan (Hasnawi dan Mustafa, 2010) dan 6,27 unit di tambak tanah sulfat masam Kecamatan Malili, Kabupaten Luwu Timur, Provinsi Sulawesi Selatan (Ratnawati, Hasnawi \& Mustafa, 2014).

Semua bahan organik mengandung karbon (C) berkombinasi dengan satu atau lebih unsur lainnya. Kandungan bahan organik yang rendah menyebabkan terhambatnya perkembangan makanan alami, sedangkan kandungan bahan organik yang terlalu tinggi akan menyebabkan tingginya kebutuhan oksigen untuk mendekomposisikannya. Kandungan bahan organik tanah di tambak Kabupaten Demak bervariasi dari 0,87 sampai $4,69 \%$ dengan rata-rata $2,76 \%$. Kandungan bahan organik tanah tambak ini tergolong rendah dan cukup berdasarkan kriteria dari Boyd et al. (2002). Hal ini juga menunjukkan bahwa tanah tambak di Kabupaten Demak tidak tergolong sebagai tanah organosol atau tanah gambut. Tanah gambut adalah tanah yang dicirikan dengan kandungan bahan organik yang melebihi 26\% (Boyd et al., 2002). 
Kebanyakan nitrogen (N) dalam tanah dasar tambak terkandung dalam bahan organik. Kandungan $\mathrm{N}$ total tanah tambak Kabupaten Demak rata-rata $0,07 \%$. Menurut Karthik et al. (2005), kandungan $\mathrm{N}$ total tanah tambak yang lebih besar dari $0,05 \%$ tergolong baik untuk budidaya tambak. Analisis konsentrasi $\mathrm{N}$ total tanah dilakukan, bukan hanya untuk mengetahui konsentrasi $\mathrm{N}$ total tanah, tetapi juga untuk mengetahui rasio $\mathrm{C}: \mathrm{N}$ tanah. Tampaknya, rasio $\mathrm{C}: \mathrm{N}$ tanah tambak di Kabupaten Demak tergolong tidak terlalu tinggi yaitu rata-rata 18,40:1. Telah dilaporkan sebelumnya bahwa rasio $\mathrm{C}: \mathrm{N}$ tanah gambut biasanya lebih besar dari 31:1 (Mustafa, 1998; Barchia, 2006). Rasio C:N tanah yang ideal untuk tambak adalah 8:1 sampai 12:1 (Boyd, 2008).

Kandungan $\mathrm{PO}_{4}$ lebih besar dari 60 ppm dalam tanah tambak dapat digolongkan sebagai slight atau tergolong baik dengan faktor pembatas yang sangat mudah diatasi (Karthik et al., 2005). Oleh karena itu, kandungan fosfat dalam tanah tambak Kabupaten Demak tergolong rendah sebab hanya berkisar antara 3,27 dan 53,01 ppm dengan ratarata $20,75 \mathrm{ppm}$.

Kandungan unsur beracun seperti Fe dan $\mathrm{Al}$ dalam tanah tambak Kabupaten Demak tergolong rendah yaitu rata-rata 529,6 dan 205,0 ppm. Di tambak tanah sulfat masam yang dicirikan dengan kandungan $\mathrm{Fe}$ dan $\mathrm{Al}$ yang tinggi dapat mencapai 4.955,7 dan 636,0 ppm di Kabupaten Luwu, Provinsi Sulawesi Selatan (Mustafa dan Sammut, 2010).

Rata-rata fraksi pasir 52,0\% dan fraksi liat 32\% di tambak Kabupaten Demak. Tekstur tanah yang demikian tergolong tekstur yang masih dapat mendukung usaha budidaya tambak. Tanah tambak sering dijumpai bertekstur halus dengan kandungan liat minimal 20-30\% untuk menahan peresapan ke samping (Boyd, 1995). Pengelolaan kualitas air mempunyai peran yang sangat penting pada keberhasilan budidaya tambak termasuk polikultur antara udang windu dan ikan bandeng. Air merupakan media hidup bagi udang windu dan ikan bandeng, berpengaruh terhadap kesehatan dan pertumbuhannya.

Kualitas air menentukan keberadaan berbagai jenis organisme yang ada dalam ekosistem tambak, baik terhadap organisme akuatik yang dibudidayakan maupun biota lainnya sebagai penyusun ekosistem tambak tersebut. Kualitas air yang jauh dari nilai optimum dapat menyebabkan kegagalan budidaya tambak, sebaliknya kualitas air yang optimum dapat mendukung pertumbuhan dan penghidupan organisme akuatik yang dibudidayakan.

Kualitas air tambak di Kabupaten Demak dapat dilihat pada Tabel 1. Salinitas air berkisar dari 7 sampai 34 ppt dengan rata-rata 23 ppt. Hal ini merupakan suatu kondisi yang sangat menguntungkan, sebab salinitas air relatif mudah diatur sesuai dengan tuntutan komoditas yang dibudidayakan, terutama pada lokasi yang dekat dengan sumber air tawar dan air asin. Udang windu mampu menyesuaikan diri terhadap salinitas air 3-45 ppt, namun untuk pertumbuhan optimum diperlukan salinitas air 15-25 ppt (Poernomo, 1988). Ikan bandeng dapat tumbuh optimum pada salinitas air 15-30 ppt (Ismail, Poernomo, Sunyoto, Wedjatmiko, Dharmadi \& Budiman, 1993).

Pertumbuhan udang terhambat pada $\mathrm{pH}$ air lebih kecil dari 6,4 (Wickins, 1984) atau lebih besar dari 8,9 (Furukawa, Hidare \& Hiramo, 1973). Seperti halnya dengan udang, klekap juga membutuhkan $\mathrm{pH}$ air netral yaitu 7,0-8,0 untuk tumbuh optimum (Ballesteros dan Mendoza, 1976). Pada pH air 7,08,5 akan dijumpai pertumbuhan ikan bandeng yang baik (Ismail et al., 1993) dan diklasifikasikan sebagai kelas S1 (sangat sesuai) dalam kriteria kesesuaian lahan dari faktor kualitas air untuk untuk budidaya ikan bandeng di tambak (Mustafa, 2012). Dari Tabel 1 menunjukkan bahwa tambak di Kabupaten Demak memiliki pH air tergolong netral sampai basa. Telah dilaporkan sebelumnya, bahwa tambak di Kabupaten Demak tergolong tanah aluvial nonsulfat masam, sehingga $\mathrm{pH}$ airnya tergolong netral sampai

Nitrat adalah bentuk utama $\mathrm{N}$ di perairan alami dan merupakan nutrien utama bagi pertumbuhan tanaman dan alga akuatik. Nitrat tidak bersifat racun terhadap organisme akuatik. Dari Tabel 1 terlihat bahwa kandungan $\mathrm{NO}_{3}$ air tambak di Kabupaten Demak berkisar antara 0,0235 sampai $6,0652 \mathrm{mg} / \mathrm{L}$ dengan rata-rata $1,6354 \mathrm{mg} / \mathrm{L}$. Kandungan $\mathrm{NO}_{3}$ ini juga tergolong tidak terlalu tinggi. Kandungan $\mathrm{NO}_{3}$ pada perairan alami hampir tidak pernah lebih besar dari $0,1 \mathrm{mg} / \mathrm{L}$. Kandungan $\mathrm{NO}_{3}$ lebih besar dari $5 \mathrm{mg} / \mathrm{L}$ menggambarkan terjadinya pencemaran antropogenik yang berasal dari aktivitas manusia dan tinja hewan (Effendi, 2003). 
Tabel 1. Statistik deskriptif produksi total, kualitas tanah, dan kualitas air di tambak Kecamatan Karangtengah dan Sayung, Kabupaten Demak, Provinsi JawaTengah

Table 1. Total production of statistic description, sold quality, and water quality on " tambak " in Karangtengah and Sayung, Demak, Central java

\begin{tabular}{|c|c|c|c|c|}
\hline Faktor/Variabel & Minimum & Maksimum & Rata-rata & Deviasi Standar \\
\hline \multicolumn{5}{|l|}{ Produksi: } \\
\hline Produksi total (kg/ha/siklus) & 300 & 2.120 & 1.105 & 661 \\
\hline \multicolumn{5}{|l|}{ Kualitas Tanah: } \\
\hline Potensial redoks (mV) & -209 & 176 & -102 & 121 \\
\hline $\mathrm{pH}_{\mathrm{F}}$ & 5,45 & 7,82 & 6,84 & 0,62 \\
\hline $\mathrm{pH}_{\mathrm{FOX}}$ & 4,00 & 7,75 & 6,64 & 2,01 \\
\hline $\mathrm{pH}_{\mathrm{F}}-\mathrm{pH}_{\mathrm{FOX}}$ & $-0,68$ & 3,95 & 0,42 & 0,84 \\
\hline $\mathrm{pH}_{\mathrm{H} 2 \mathrm{O}}$ & 7,72 & 8,54 & 8,29 & 0,23 \\
\hline $\mathrm{pH}_{\mathrm{KCl}}$ & 6,96 & 8,00 & 7,66 & 0,25 \\
\hline Bahan Organic (\%) & 0,87 & 4,69 & 2,76 & 1,12 \\
\hline $\mathrm{N}$ total $(\%)$ & 0,02 & 0,11 & 0,07 & 0,03 \\
\hline InRasio $\mathrm{C}: \mathrm{N}$ & 4,30 & 84,31 & 18,40 & 14,31 \\
\hline $\mathrm{PO}_{4}(\mathrm{ppm})$ & 3,27 & 53,01 & 20,75 & 17,26 \\
\hline $\mathrm{Fe}(\mathrm{ppm})$ & 82,8 & $1.025,3$ & 529,6 & 236,0 \\
\hline $\mathrm{Al}(\mathrm{ppm})$ & 0,1 & 300,8 & 205,0 & 90,0 \\
\hline Pasir $(\%)$ & 36 & 88 & 52 & 19 \\
\hline Debu $(\%)$ & 6 & 32 & 18 & 9 \\
\hline Liat $(\%)$ & 0 & 48 & 30 & 18 \\
\hline \multicolumn{5}{|l|}{ Kualitas Air: } \\
\hline Salinitas (ppt) & 7 & 34 & 23 & 6 \\
\hline $\mathrm{pH}$ & 6,19 & 8,02 & 7,43 & 0,53 \\
\hline $\mathrm{NO}_{3}(\mathrm{mg} / \mathrm{L})$ & 0,0235 & 6,0652 & 1,6354 & 1,5759 \\
\hline $\mathrm{NO}_{2}(\mathrm{mg} / \mathrm{L})$ & 0,0001 & 0,2580 & 0,0268 & 0,0703 \\
\hline $\mathrm{NH}_{3}(\mathrm{mg} / \mathrm{L})$ & 0,1052 & 0,7830 & 0,3472 & 0,2211 \\
\hline $\mathrm{PO}_{4}(\mathrm{mg} / \mathrm{L})$ & 0,0372 & 0,4593 & 0,1216 & 0,1204 \\
\hline Bahan organik total (mg/L) & 20,60 & 54,77 & 36,91 & 11,15 \\
\hline
\end{tabular}

Sumber: Statistik Kabupaten Demak

Nitrit merupakan bentuk peralihan antara $\mathrm{NH}_{3}$ dan $\mathrm{NO}_{3}$ (nitrifikasi) dan antara $\mathrm{NO}_{3}$ dan gas nitrogen $\left(\mathrm{N}_{2}\right)$ (denitrifikasi). Nitrit kurang beracun dibandingkan dengan $\mathrm{NH}_{3}$, tetapi tetap sangat beracun karena menghambat kemampuan darah dalam membawa oksigen. Kandungan $\mathrm{NO}_{2}$ air tambak Kabupaten Demak berkisar 0,0001 sampai dengan $0,2580 \mathrm{mg} / \mathrm{L}$ dengan rata-rata $0,0268 \mathrm{mg} / \mathrm{L}$ yang tergolong tidak terlalu tinggi. Kandungan $\mathrm{NO}_{2}$ pada perairan relatif kecil karena segera dioksidasi menjadi $\mathrm{NO}_{3}$. Perairan alami mengandung $\mathrm{NO}_{2}$ sekitar $0,001 \mathrm{mg} / \mathrm{L}$ dan sebaiknya tidak melebihi $0,06 \mathrm{mg} / \mathrm{L}$ (CCREM, 1987). Di perairan, kandungan $\mathrm{NO}_{2}$ jarang melebihi $1 \mathrm{mg} / \mathrm{L}$ (Sawyer dan McCarty, 1978).
Kandungan $\mathrm{NO}_{2}$ yang lebih besar dari $0,05 \mathrm{mg} / \mathrm{L}$ dapat bersifat racun bagi organisme akuatik yang sangat sensitif (Moore, 1991).

Amonia dapat berada dalam bentuk tak terionisasi yaitu $\mathrm{NH}_{3}$ atau bentuk ion $\mathrm{NH}_{4}{ }^{+}$, dimana $\mathrm{NH}_{3}$ lebih beracun daripada $\mathrm{NH}_{4}$ (Poernomo, 1988), jumlah keduanya dikenal sebagai nitrogen-amonia total atau total ammonia-nitrogen (TAN) (Montoya, Lawrence, Grant \& Velasco, 2002). Amonia merupakan bentuk utama ekskresi $\mathrm{N}$ dari organisme akuatik. Sumber utama $\mathrm{NH}_{3}$ adalah bahan organik dalam bentuk sisa pakan, kotoran ikan maupun dalam bentuk plankton dari bahan organik tersuspensi. Dekomposisi bahan organik, 
terutama yang banyak mengandung protein, menghasilkan amonium $\left(\mathrm{NH}_{4}^{+}\right)$dan $\mathrm{NH}_{3}$. Bila proses lanjut dari dekomposisi (nitrifikasi) tidak berjalan lancar, maka dapat terjadi penumpukan $\mathrm{NH}_{3}$ sampai pada kandungan yang membahayakan bagi ikan. Amonia dapat menembus bagian membran sel lebih cepat daripada $\mathrm{NH}_{4}$ (Colt dan Armstrong, 1981). Kandungan $\mathrm{NH}_{3}$ 0,05-0,20 $\mathrm{mg} / \mathrm{L}$ sudah menghambat pertumbuhan organisme akuatik pada umumnya. Apabila kandungan $\mathrm{NH}_{3}$ lebih besar dari $0,20 \mathrm{mg} / \mathrm{L}$, perairan bersifat racun bagi beberapa jenis ikan (Sawyer dan McCarty, 1978). Ikan tidak dapat bertoleransi terhadap kandungan $\mathrm{NH}_{3}$ yang terlalu tinggi, karena dapat mengganggu proses pengikatan oksigen oleh darah dan pada akhirnya dapat mengakibatkan sufokasi. Menurut Djajadiredja, Jangkaru \& Omiarsa (1980), perairan yang mengandung $\mathrm{NH}_{3}$ tidak lebih besar dari $0,1 \mathrm{mg} / \mathrm{L}$ dianggap perairan normal, sedangkan jika mengandung lebih besar dari 1 $\mathrm{mg} / \mathrm{L}$ dianggap perairan tercemar. Berdasarkan dari beberapa pendapat tersebut menunjukkan bahwa kandungan $\mathrm{NH}_{3}$ tergolong cukup tinggi di tambak Kabupaten Demak yang berkisar antara 0,1052 dan $0,7830 \mathrm{mg} / \mathrm{L}$ dengan rata-rata 0,3472 $\mathrm{mg} / \mathrm{L}$.

Unsur fosfor (P) di perairan tidak ditemukan dalam bentuk bebas sebagai elemen, melainkan dalam bentuk senyawa anorganik yang terlarut (ortofosfat dan polifosfat) dan senyawa organik yang berupa partikulat. Fosfat merupakan bentuk fosfor yang dapat dimanfaatkan oleh tanaman (Dugan, 1972). Kandungan $\mathrm{PO}_{4}$ pada perairan alami jarang melebihi $1 \mathrm{mg} / \mathrm{L}$ (Boyd, 1988). Berdasarkan kandungan $\mathrm{PO}_{4}$, perairan diklasifikasikan menjadi tiga yaitu: perairan dengan kesuburan rendah, yang memiliki kandungan $\mathrm{PO}_{4}$ berkisar antara 0-0,02 $\mathrm{mg} / \mathrm{L}$; perairan dengan tingkat kesuburan sedang, yang memiliki kandungan $\mathrm{PO}_{4}$ 0,021-0,05 mg/L; dan perairan dengan tingkat kesuburan tinggi, yang memiliki kandungan $\mathrm{PO}_{4}$ 0,051-0,10 mg/L (Liaw, 1969). Berdasarkan kriteria tersebut menunjukkan bahwa kualitas air tambak di Kabupaten Demak tergolong tingkat kesuburan sedang, tinggi dan sangat tinggi.

Bahan organik total air menggambarkan kandungan bahan organik total suatu perairan yang terdiri dari bahan organik terlarut, tersuspensi dan koloid. Bahan organik total di perairan terdapat sebagai plankton, partikel-partikel tersuspensi dari bahan organik yang mengalami dekomposisi (detritus) dan bahan-bahan organik total yang berasal dari daratan dan terbawa oleh aliran sungai. Kandungan bahan organik total air di tambak Kabupaten Demak berkisar 20,60 dan 54,77 mg/L dengan rata-rata 36,91 mg/L (Tabel 1). Kandungan bahan organik total dalam air laut biasanya rendah dan tidak melebihi $3 \mathrm{mg} / \mathrm{L}$. Menurut Reid (1961), perairan dengan kandungan bahan organik total lebih besar dari $26 \mathrm{mg} / \mathrm{L}$ adalah tergolong perairan yang subur.

\subsection{Hubungan Kualitas Tanah dan Air dengan Produksi Total Tambak}

Telah disebutkan sebelumnya bahwa variabel kualitas tanah merupakan variabel independen dan variabel eksogen dalam penelitian ini. Dari 14 variabel kualitas tanah (Tabel 1) yang dianalisis ternyata hanya 2 variabel yang mempengaruhi produksi total (udang windu dan ikan bandeng) di tambak Kabupaten Demak yaitu: bahan organik dan $\mathrm{PO}_{4}$ (Gambar 2). Bahan organik tanah berpengaruh sangat nyata dengan pengaruh langsung sebesar $0,404(P<0,01)$ terhadap produksi total, sedangkan $\mathrm{PO}_{4}$ tanah berpengaruh nyata dengan pengaruh langsung sebesar $0,267(P<0,10)$ terhadap produksi total. Dari 7 variabel kualitas air yang merupakan variabel perantara, dependen dan endogen dalam penelitian ini, ternyata ada 3 variabel yang mempengaruhi produksi total tambak di Kabupaten Demak yaitu: $\mathrm{PO}_{4}$, salinitas dan $\mathrm{NO}_{3}$ (Gambar 2). Seperti telah dilaporkan sebelumnya oleh Deepak dan Singh (2014) bahwa kondisi fisika-kimia air berpengaruh langsung terhadap sintasan, pertumbuhan, reproduksi dan distribusi ikan. Fosfat air berpengaruh nyata $(P<0,10)$ terhadap produksi total, sedangkan salinitas dan $\mathrm{NO}_{3}$ air berpengaruh sangat nyata $(P<0,01)$ terhadap produksi total dengan pengaruh langsung masing-masing 0,117, -0,414 dan 0,377. Kedua variabel kualitas tanah yang berpengaruh terhadap produksi total tersebut ternyata berpengaruh nyata terhadap kualitas air tambak. Dalam hal ini, pengaruh nyata kualitas tanah terhadap produksi total juga melalui variabel perantara kualitas air. Dari Gambar 2 terlihat bahwa bahan organik tanah berpengaruh sangat nyata $(P<0,01)$ terhadap $\mathrm{NO}_{3}$ air dengan pengaruh langsung $-0,416$, sedangkan $\mathrm{PO}_{4}$ tanah berpengaruh sangat nyata $(P<0,01)$ terhadap $\mathrm{PO}_{4}$ dan $\mathrm{NO}_{3}$ air dengan pengaruh langsung masingmasing 0,586 dan 0,540. Pengaruh langsung (direct effect), pengaruh tidak langsung (indirect 
effect) dan pengaruh total (total effect) antarvariabel secara lengkap tersaji pada Tabel 2.

Di antara variabel kualitas tanah yang mempengaruhi produksi total yaitu bahan organik dan $\mathrm{PO}_{4}$, ternyata kedua variabel kualitas tanah tersebut juga saling mempengaruhi. Pengaruh bahan organik terhadap ketersediaan $\mathrm{P}$ dapat secara langsung melalui proses mineralisasi atau secara tidak langsung dengan membantu pelepasan $\mathrm{P}$ yang terfiksasi. Stevenson (1982) menjelaskan ketersediaan $\mathrm{P}$ dalam tanah dapat ditingkatkan dengan penambahan bahan organik melalui lima aksi yaitu: (a) melalui proses mineralisasi bahan organik yang melepaskan $\mathrm{P}$ mineral $\left(\mathrm{PO}_{4}\right),(\mathrm{b})$ melalui aksi dari asam organik atau senyawa pengkhelat yang lain dari hasil dekomposisi, terjadi pelepasan fosfat yang berikatan dengan $\mathrm{Fe}$ dan $\mathrm{Al}$ yang tidak larut menjadi bentuk terlarut, (c) bahan organik akan mengurangi jerapan $\mathrm{PO}_{4}$ karena asam humat dan asam fulvat berfungsi melindungi sesquioksida dengan memblokir lokasi pertukaran, (d) penambahan bahan organik mampu mengaktifkan proses dekomposisi bahan organik asli tanah dan (e) membentuk kompleks fosfohumat dan fosfo-fulvat yang dapat ditukar dan lebih tersedia, sebab $\mathrm{PO}_{4}$ dijerap bahan organik secara lemah. Dikatakan pula oleh Kassila et al. (2001), akumulasi bahan organik tanah atau sedimen dalam kondisi anaerob dapat meningkatkan pelepasan $\mathrm{PO}_{4}$ dari $\mathrm{CaCO} \approx \mathrm{P}$ yang labil dalam tanah atau sedimen tambak dan meningkatkan produktivitas fitoplankton yang bertanggung jawab untuk memperbaharui akumulasi bahan organik.

Telah disebutkan sebelumnya bahwa bahan organik tanah berpengaruh terhadap produksi total tambak di Kabupaten Demak dengan pengaruh total 0,619 yang menunjukkan bahwa 61,90\% produksi total tambak dipengaruhi oleh bahan organik tanah dan sisanya sebesar 38,10\% dipengaruhi oleh variabel kualitas tanah lainnya serta pengaruhnya bersifat positif yang artinya peningkatan bahan organik tanah akan meningkatkan produksi total. Bahan organik tanah seringkali menjadi bahan pertimbangan dalam pengelolaan budidaya tambak. Bahan organik tanah dapat mempengaruhi sifat kimia, biologi dan fisikatanah. Bahan organik yang terdekomposisi dapat menjadi sumber $\mathrm{N}$, sehingga kesuburan tanah tambak dapat meningkat yang berdampak pula pada peningkatan makanan alami dan produksi tambak. Bahan organik dapat menjadi sumber makanan bagi mikroorganisme, sehingga kondisi tanah dasar juga dapat lebih baik yang berdampak pada peningkatan produksi tambak. Menurut Brussaard (1994) serta Bot dan Benites (2005) organisme tanah termasuk mikroorganisme menggunakan bahan organik tanah sebagai makanan dan dari hasil dekomposisi bahan organik akan dihasilkan berbagai nutrien (N, P dan $\mathrm{S}$ ) yang dilepaskan ke dalam tanah dalam berbagai bentuk yang dapat digunakan oleh tanaman. Bahan organik dapat berfungsi sebagai granulator yaitu memperbaiki struktur tanah tambak menjadi lebih baik, sehingga kondisi tambak juga menjadi lebih baik untuk produksi. Seperti dikatakan oleh Bot dan Benites (2005) bahwa salah satu peran penting bahan organik tanah adalah menjadi perekat partikel tanah untuk membentuk struktur tanah terbaik. Dekomposisi bahan organik menjadi humus menciptakan partikel molekul humus yang berfungsi sebagai "semen" dari fraksi pasir, debu dan liat dari tanah dalam agregat yang tidak mudah hancur dalam air (Christensen, 1986). Telah disebutkan sebelumnya bahwa kandungan bahan organik tanah tambak di Kabupaten Demak relatif rendah sehingga peningkatan bahan organik tanah dapat meningkatkan produksi total tambak. Telah dilaporkan pula bahwa fraksi pasir adalah fraksi dari tekstur tanah yang dominan di tanah tambak Kabupaten Demak (berkisar antara 36 dan 88\% dengan rata-rata 52\%), sehingga pemberian bahan organik dapat memperbaiki struktur tanah dan mengurangi porositas pematang. Bahan organik tanah merupakan salah satu bahan pembentuk agregat tanah, yang mempunyai peran sebagai perekat antar partikel tanah untuk bersatu menjadi agregat tanah, sehingga bahan organik menjadi penting dalam pembentukan struktur tanah. Pada tanah berpasir yang banyak mengandung pori makro yang tidak dapat menahan air, maka penambahan bahan organik akan meningkatkan pori berukuran menengah dan menurunkan pori berukuran makro sehingga meningkatkan kemampuan tanah dalam menahan air. Oleh karena itu peningkatan kandungan bahan organik tanah dapat mengurangi porositas pematang tambak, sehingga ketinggian air tambak relatif dapat dipertahankan yang berdampak pada kondisi tambak yang lebih baik untuk udang windu dan ikan bandeng yang dibudidayakan. Sebagai akibat dari banyaknya pengaruh bahan organik tanah terhadap kualitas tanah lainnya menjadi penyebab munculnya pengaruh tidak langsung yang cukup 
besar dari bahan organik tanah terhadap produksi total tambak di Kabupaten Demak seperti terlihat pada Tabel 2.

Fosfor merupakan faktor pembatas produktivitas primer di tambak. Fosfor memainkan peran penting dalam fotosintesis, respirasi, cadangan dan transferenergi, pembelahan sel, pembesaran sel dan beberapa proses lainnya (Price, 2006). Pengaruh total dari $\mathrm{PO}_{4}$ tanah terhadap produksi total tambak di Kabupaten Demak sebesar 0,329 yang berarti $32,90 \%$ produksi total tambak dipengaruhi oleh $\mathrm{PO}_{4}$ tanah, di mana pengaruh $\mathrm{PO}_{4}$ tanah bersifat positif yang berarti peningkatan kandungan $\mathrm{PO}_{4}$ tanah berdampak pada peningkatan produksi total tambak di Kabupaten Demak. Hal ini dapat dimengerti, sebab kandungan $\mathrm{PO}_{4}$ tanah di tambak Kabupaten Demak tergolong rendah (rata-rata 20,75 ppm), sehingga dengan peningkatan kandungan $\mathrm{PO}_{4}$ tanah akan meningkatkan produksi total di tambak. Telah disebutkan sebelumnya bahwa kandungan $\mathrm{PO}_{4}$ tanah lebih besar dari 60 ppm tergolong sangat baik baik untuk budidaya tambak (Karthik et al., 2005).

Fosfor merupakan unsur yang esensial bagi tanaman tingkat tinggi dan alga akuatik, sehingga unsur ini menjadi faktor pembatas bagi tanaman dan alga akuatik serta sangat mempengaruhi tingkat produktivitas perairan. Davis dan Cornwell (1991) mengemukakan korelasi positif antara kandungan $\mathrm{PO}_{4}$ dengan klorofil-a. Mungkin inilah salah satu penyebab terjadinya peningkatan produksi total tambak di Kabupaten Demak seiring dengan peningkatan kandungan $\mathrm{PO}_{4}$ dalam tambak.

Udang windu dan ikan bandeng merupakan organisme eurihalin, namun karena dibudidayakan untuk tujuan komersial, kisaran salinitas air yang optimum perlu dipertahankan. Salinitas air memainkan peran penting bagi udang windu dan ikan bandeng yang dibudidayakan melalui osmoregulasi mineral tubuh dari air di sekitarnya. Salinitas air sangat berpengaruh terhadap produksi total tambak di Kabupaten Demak dengan pengaruh total $-0,760$ (Gambar 2 dan Tabel 2) yang berarti $76,00 \%$ produksi total tambak dipengaruhi oleh salinitas air, di mana penurunan salinitas air akan meningkatkan produksi total. Telah dilaporkan bahwa udang windu dan ikan bandeng tumbuh dengan baik pada salinitas air optimum berturut-turut 15-25 (Poernomo, 1988) dan 15-30 ppt (Ismail et al., 1993), yang merupakan kondisi salinitas air yang paling ideal untuk budidaya pembesaran di tambak karena memberikan kondisi lingkungan yang sesuai dengan tingkat osmotik cairan tubuh udang windu dan ikan bandeng. Telah dilaporkan pula bahwa produksi polikultur udang windu dan ikan bandeng tertinggi di tambak didapatkan pada salinitas air 16,3 ppt (Mustafa et al., 2007). Oleh karena salinitas air di tambak Kabupaten Demak mencapai 34 ppt, sehingga penurunan salinitas air sampai mendapatkan salinitas air optimum bagi udang windu dan ikan bandeng menyebabkan peningkatan produksi total tambak. Hal ini didukung dengan kenyataan bahwa di berbagai daerah di Indonesia telah berkembang budidaya udang dan ikan bandeng pada lahan tambak bersalinitas air rendah (lebih kecil dari $10 \mathrm{ppt}$ ) untuk mencegah terjangkitnya penyakit penyebab kematian udang (Sudradjat dan Wedjatmiko, 2010).

Lapisan teroksidasi (oxydized layer) akan ditemukan pada dasar tambak yang merupakan lapisan sedimen paling atas yang mengandung oksigen. Lapisan ini sangat bermanfaatdan harus dipelihara keberadaannya selama siklus budidaya (Boyd, 2002). Pada lapisan tersebut terjadi dekomposisi aerobik yang menghasilkan antara lain: karbon dioksida $\left(\mathrm{CO}_{2}\right), \mathrm{NH}_{3}$ dan nutrien yang lainnya. Pada sedimen anaerobik, beberapa mikroorganisme mendekomposisikan material organik dengan reaksi fermentasi yang menghasilkan alkohol, keton, aldehida, dan senyawa organik lainnya sebagai hasil metabolisme. Menurut Boyd (2002), beberapa mikroorganisme anaerobik dapat memanfaatkan $\mathrm{O}_{2}$ dari $\mathrm{NO}_{3}, \mathrm{NO}_{2}$, ferro $\left(\mathrm{Fe}^{2+}\right), \mathrm{SO}_{4}$ dan $\mathrm{CO}_{2}$ untuk mendekomposisikan bahan organik dengan mengeluarkan $\mathrm{N}_{2}, \mathrm{NH}_{3}, \mathrm{H}_{2} \mathrm{~S}$, dan metan $\left(\mathrm{CH}_{4}\right)$ sebagai hasil metabolisme. Dari uraian tersebut diduga pengaruh total dari bahan organik tanah yang menyebabkan penurunan kandungan $\mathrm{NO}_{3}$ air dalam mempengaruhi produksi total tambak sebagai akibat dari $\mathrm{NO}_{3}$ air yang dimanfaatkan oleh mikroorganisme dalam mendekomposisikan bahan organik tanah tambak di Kabupaten Demak, seperti yang ditunjukkan oleh pengaruh total sebesar -0,182 (Gambar 2 dan Tabel 2).

Fosfor yang ada dalam tambak berasal dari pupuk serta dari pakan. Fosfor dimanfaatkan oleh fitoplankton dalam bentuk $\mathrm{PO}_{4}$ dan terakumulasi dalam tubuh ikan/udang melalui rantai makanan. Fosfat yang tidak diserap oleh fitoplankton akan 


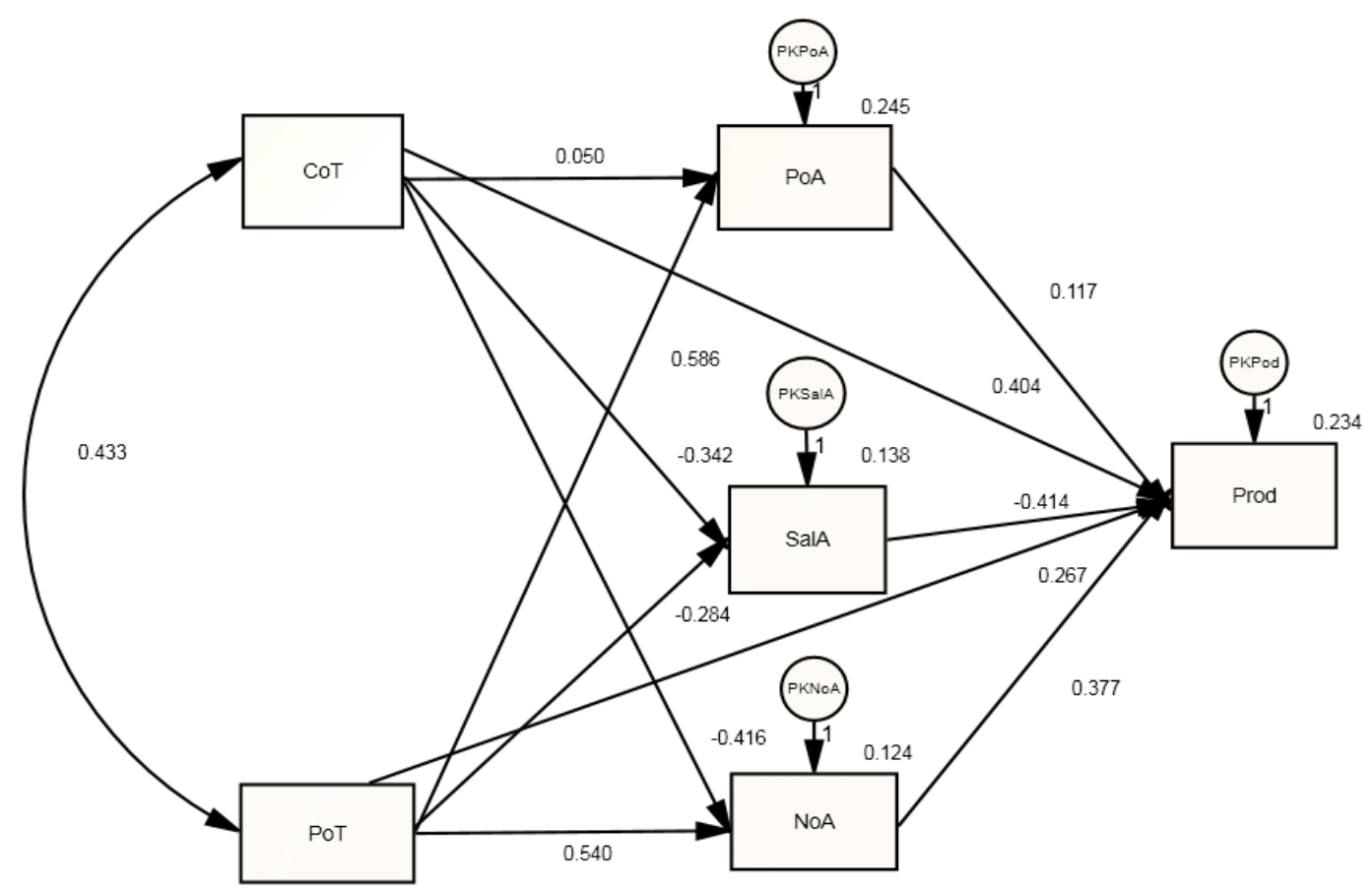

Keterangan:

CoT : bahan organik tanah

PoT : fosfat tanah

SalA : salinitas air

PoA : fosfat air

NoA : nitrat air

Prod : produksi total

Gambar 2. Diagram hasil analisis jalur kualitas tanah terhadap kualitas air dan produksi total di tambak Kecamatan Karangtengah dan Sayung, Kabupaten Demak,

Provinsi Jawa Tengah

Figure 2. Analysis of result quality road of sold depend on water quality and total production in "tambak" Karangtengah and Sayung, Demak, Central Java Sumber: Hasil analisis data

Tabel 2. Nilai pengaruh langsung, tidak langsung dan total setiap korelasi dalam analisis jalur untuk kualitas tanah, kualitas air dan produksi total di tambak Kecamatan

Karangtengah dan Sayung, Kabupaten Demak, Provinsi Jawa Tengah

Table 2. Direct value, nondirect value and total corelation in road analysis for sold quality, water quality and total production in "tambak" Karangtengah and Sayung, Demak, Central Java

\begin{tabular}{lccc}
\hline $\begin{array}{c}\text { Korelasi dalam } \\
\text { Analisis Jalur }\end{array}$ & Pengaruh Langsung & Pengaruh Tidak Langsung & Pengaruh Total \\
\hline CoT $\rightarrow$ PoA & & & 0,304 \\
CoT $\rightarrow$ SalA & 0,050 & 0,254 & $-0,465$ \\
CoT $\rightarrow$ NoA & $-0,342$ & $-0,123$ & $-0,182$ \\
PoT $\rightarrow$ PoA & $-0,416$ & 0,234 & 0,608 \\
PoT $\rightarrow$ SalA & 0,586 & 0,022 & $-0,232$ \\
PoT $\rightarrow$ NoA & $-0,084$ & $-0,148$ & 0,360 \\
CoT $\rightarrow$ Prod & 0,540 & $-0,180$ & 0,619 \\
PoT $\rightarrow$ Prod & 0,404 & 0,215 & 0,329 \\
PoA $\rightarrow$ Prod & 0,267 & 0,062 & 0,133 \\
SalA $\rightarrow$ Prod & 0,117 & 0,016 & $-0,760$ \\
NoA $\rightarrow$ Prod & $-0,414$ & $-0,346$ & 0,434 \\
\hline
\end{tabular}

Sumber: Hasil analisis data

Keterangan:

CoT : bahan organik tanah

PoT : fosfat tanah

SalA : salinitas air

PoA : fosfat air

NoA : nitrat air

Prod : produksi total

Aplikasi Analisis Jalur dalam Penentuan Pengaruh Kualitas Tanah dan Air Terhadap Produksi Total Tambak di Kabupaten Demak, Provinsi Jawa Tengah - Akhmad Mustafa dan Admi Athirah 
diiikat oleh tanah. Oleh karena itu, pengaruh tidak langsung dari $\mathrm{PO}_{4}$ tanah terhadap produksi total tambak di Kabupaten Demak melalui pengaruhnya terhadap $\mathrm{PO}_{4}$ air (Gambar 2), diduga sebagai akibat $\mathrm{PO}_{4}$ yang ada dalam tambak yang tidak diikat oleh tanah akan larut dalam air. Kemampuan tanah mengikat $\mathrm{PO}_{4}$ dipengaruhi oleh kandungan liat tanah. Semakin tinggi kandungan liat pada tanah, semakin meningkat kemampuan tanah mengikat fosfat. Dari Gambar 2 dan Tabel 2 menunjukkan bahwa $\mathrm{PO}_{4}$ air berpengaruh terhadap produksi total dengan pengaruh total sebesar 0,133 . Variabel kualitas air lain yang berpengaruh terhadap produksi total tambak di Kabupaten Demak adalah $\mathrm{NO}_{3}$ dengan pengaruh total sebesar 0,434 yang berarti $43,40 \%$ produksi total tambak dipengaruhi oleh $\mathrm{NO}_{3}$ air dan sisanya yaitu sebesar $56,60 \%$ disebabkan oleh variabel kualitas air lainnya serta pengaruh $\mathrm{NO}_{3}$ air bersifat positif di mana peningkatan kandungan $\mathrm{NO}_{3}$ air akan meningkatkan produksi total tambak. Nitrat merupakan salah satu bentuk $\mathrm{N}$ yang dapat dimanfaatkan secara langsung oleh tanaman akuatik selain $\mathrm{NH}_{4}$ dan $\mathrm{N}_{2}$. Nitrat adalah bentuk utama $\mathrm{N}$ di perairan alami dan merupakan nutrien yang penting untuk budidaya tambak sebab $\mathrm{NO}_{3}$ inilah yang dimanfaatkan tanaman dan alga akuatik. Chu (1943) mendapatkan bahwa kandungan $\mathrm{NO}_{3}$ yang optimum untuk pertumbuhan plankton adalah 0,9-3,5 mg/L. Smayda (1983) menyatakan bahwa plankton secara umum lebih suka memanfaatkan $\mathrm{N}$ dalam bentuk $\mathrm{NO}_{3}, \mathrm{NO}_{2}$ dan $\mathrm{NH}_{3}$, sehingga dalam kondisi ini, $\mathrm{NO}_{3}$ yang dimanfaatkan lebih dahulu untuk pertumbuhannya. Dari Tabel 1 terlihat bahwa rata-rata kandungan $\mathrm{NO}_{3}$ air di tambak adalah $1,6354 \mathrm{mg} / \mathrm{L}$, sehingga peningkatan kandungan $\mathrm{NO}_{3}$ air sampai batas tertentu dapat meningkatkan produksi total tambak di Kabupaten Demak.

\section{KESIMPULAN DAN SARAN}

Kualitas tanah dan air tambak di Kabupaten Demak dapat mendukung usaha budidaya tambak sistem polikultur udang windu dan ikan bandeng dengan produksi total antara 300 dan 2.120 $\mathrm{kg} / \mathrm{ha} / \mathrm{siklus}$ atau rata-rata $1.105 \mathrm{~kg} / \mathrm{ha} /$ siklus. Hasil analisis jalur dari 14 variabel kualitas tanah yang dianalisis ternyata hanya 2 variabel yang mempengaruhi produksi total yaitu: kandungan bahan organik dan fosfat, sedangkan dari 7 variabel kualitas air, ternyata ada 3 variabel yang mempengaruhi produksi total tambak Kabupaten Demak yaitu kandungan fosfat, salinitas dan nitrat. Kedua variabel kualitas tanah tersebut juga memiliki pengaruh tidak langsung terhadap produksi total tambak melalui pengaruhnya terhadap fosfat, salinitas dan nitrat air. Aplikasi pupuk organik dan pupuk anorganik yang mengandung fosfat pada tanah serta aplikasi pupuk anorganik yang mengandung fosfat dan nitrogen pada air serta penurunan salinitas air diharapkan dapat meningkatkan produktivitas tambak di Kabupaten Demak.

\section{UCAPAN TERIMA KASIH}

Diucapkan banyak terima kasih kepada Muhammad Arnol dan Rosiana Sabang atas bantuannya di lapangan; Rahmiyah dan Kamariah atas bantuannya dalam analisis kualitas tanah di laboratorium; serta Sitti Rohani, Andi Sahrijanna dan Kurnia atas bantuannya dalam analisis air di laboratorium.

\section{DAFTAR PUSTAKA}

Agus, Yusrial, F. dan Sutono. (2006). Penetapan tekstur tanah. Dalam: Kurnia, U., Agus, F., Adimihardja, A. dan Dariah, A. (eds.), Sifat Fisik Tanah dan Metode Analisisnya. Balai Besar Penelitian dan Pengembangan Sumberdaya Lahan Pertanian, Bogor.hlm. 43-62.

Ahern, C.R., Blunden, B., Sullivan, L.A.and McElnea, A.E. (2004). Soil sampling, handling, preparation and storage for analisys of dried samples. In: Acid Sulfate Soils Laboratory Methods Guidelines. Queensland Department of Natural Resources, Mines and Energy, Indooroopilly, Queensland. pp. B1-1-B1-5.

Amir, M.F. (2006). Mengolah dan Membuat Interpretasi Hasil Olahan SPSS untuk Penelitian Ilmiah. EDSA Mahkota, Jakarta. $201 \mathrm{hlm}$

Anonim. (2011). Peningkatan dan Pemuktakhiran Data Perikanan: Rumah Tangga Perikanan (RTP) Budidaya Tambak. Dinas Kelautan dan Perikanan Kabupaten Demak, Demak.116 hlm.

APHA (American Public Health Association).(2005). Standard Methods for Examination of Water and Wastewater. Twentieth edition APHA-AWWAWEF, Washington, 1185 pp.

Athirah, A., Asaf, R. dan Ratnawati, E. (2013). Faktor lingkungan yang mempengaruhi produktivitas menggunakan aplikasi analisis jalur di tambak 
bandeng Kabupaten Indramayu, Provinsi Jawa Barat. Jurnal Kelautan Nasional, 8(1), 35-47.

Avnimelech, Y. and Ritvo, G. (2003). Shrimp and fish pond soils: processes and management. Aquaculture, 220, 549-567.

Ballesteros, O.Q., and Mendoza, S.P. (1976). Brackish fishpond management. In: Lopez, A.M. (ed.), Pond Construction and Management. Western Visayas Federation of Fish Producers Inc., Iloilo City. pp. 19-27.

Barchia, M.F. (2006). Gambut: Agroekosistem dan Transformasi Karbon. Gadjah Mada University Press, Yogyakarta. $196 \mathrm{hlm}$.

Bot, A. and Benites, J. (2005). The Importance of Soil Organic Matter: Key to Drought-resistant Soil and Sustained Food Production. FAO Soils Bulletin 80.Food and Agriculture Organization of the United Nations, Rome.79 pp.

Boyd, C.E. (1988). Water Quality in Warmwater Fish Ponds. Fourth printing.Alabama Agricultural Experiment Station, Auburn University, Alabama. 359 pp.

Boyd, C.E. (1992). Shrimp pond bottom soil and sediment management. In: Wyban, J. (ed.), Proceedings of the Special Session on Shrimp Farming. World Aquaculture Society, Baton Rouge, Louisiana. pp. 166-181.

Boyd, C.E. (1995). Bottom Soils, Sediment, and Pond Aquaculture. Chapman and Hall, New York.348 pp.

Boyd, C.E. (2002). Understanding pond pH. Global Aquaculture Advocate, June: 2 pp.

Boyd, C.E. (2008). Pond bottom soil analyses. Global Aquaculture Advocate September/October: 9192.

Boyd, C.E., Wood, C.W. and Thunjai, T. (2002). Aquaculture Pond Bottom Soil Quality Management. Pond Dynamics/Aquaculture Collaborative Research Support Program Oregon State University, Corvallis, Oregon.41 pp.

Brussaard, L. (1994). Interrelationships between biological activities, soil properties and soil management. In: Greenland, D.J. and Szabolcs (eds.), Soil Resilience and Sustainable Land Use. CAB International, Wallingford, UK. pp. 309329.

CCREM (Canadian Councilof Resource and Environment Ministers). (1987). Canadian Water Quality Guidelines. Canadian Councilof Resource and Environment Ministers, Task Force on Water Quality Guidelines. Environment Canada. Ottawa, Ontario. Canada; 6 Chapters plus XXII Appendices.

Christensen, B.T. (1986). Straw incorporation and soil organic matter in macro-aggregates and particle size separates. Journal of Soil Science, 37, 125135.
Chu, S.P. (1943). The influence the mineral composition of the medium on the growth of planktonic algae. Part II: The influence of the concentration of inorganic nitrogen and phosphate phosphorus. Journal of Ecology, 31(2), 109-148.

Colt, J.E. and Armstrong, D.A. (1981). Nitrogen toxicity to crustaceans, fish, and molluscs. In: Allen,L.J. and Kinney,E.C. (eds.), Proceedings of the Bio-engineering Symposium for Fish Culture. American Fisheries Society, Bethesda, MD.pp. 34-37.

Davis, M.L. and Cornwell, D.A. (1991). Introduction to Environmental Engineering. Second edition. McGraw-Hill, Inc., New York.822 pp.

Deepak, S. and Singh, N.U. (2014). The relationship between physico-chemical characteristics and fish production of Mod sagar reservoir of Jhabua District, MP, India. Research Journal of Recent Sciences, 3, 822-826.

Djajadiredja, R., Jangkaru, Z. dan Omiarsa, S. (1980). Mekanisme dalam usaha peningkatan dan guna air tawar untuk budidaya ikan secara intensif. Dalam: Lokakarya Nasional Teknologi Tepat Guna Bagi Pengembangan Air Payau. Lembaga Penelitian Perikanan Darat, Bogor. 9 hlm

Draper, N.R. and Smith, H. (1981). Applied Regression Analysis.Second edition. John Wiley \& Sons, New York. 709 pp.

Dugan, P.R. (1972). Biochemical Ecology of Water Pollution. Plenum Press, New York. 159 pp.

Effendi, H. (2003). Telaah Kualitas Air bagi Pengelolaan Sumber Daya dan Lingkungan Perairan. Penerbit Kanisius, Yogyakarta. 258 hlm.

Eldani, A. and Primavera, J.H. (1981). Effect of different stocking combination of growth, production and survival rate of milkfish (Chanos chanos Forskal) and prawn (Penaeus monodon Fabricius) in polyculture in brackishwater ponds.Aquaculture 23: 59-72.

Everitt, B.S. and Dunn, G. (2001). Applied Multivariate Data Analysis.Second edition. Arnold, London. 342 pp.

Eviati dan Sulaeman. (2009). Analisis Kimia Tanah, Tanaman, Air, dan Pupuk. Petunjuk Teknis Edisi 2. Balai Penelitian Tanah, Bogor. 234 hlm.

Furukawa, I., Hidare, H. and Hiramo, K. (1973). Production of prawn seed by marine yeast. Research Report Faculty of Agriculture Miyosaki University, 20(1), 93-110.

Grasshoff, K. (1976). Methods of Seawater Analysis. Verlag Chemie, Weinheim, New York. 317 pp.

Hanafi, A. (1990). Socio-economic and managerial profiles of brackishwater aquaculture in South Sulawesi. Jurnal Perikanan Budidaya Pantai, 6(2), 97-114. 
Hardjowigeno, S. dan Widiatmaka. (2011). Evaluasi Kesesuaian Lahan \& Perencanaan Tataguna Lahan. Gadjah Mada University Press, Yogyakarta. $352 \mathrm{hlm}$.

Hasnawi dan Mustafa, A. (2010). Karakteristik, kesesuaian, dan pengelolaan lahan untuk budidaya tambak di Kabupaten Luwu Utara, Provinsi Sulawesi Selatan. Jurnal Riset Akuakultur, 5(3), 449-463.

Ismail, A., Poernomo, A., Sunyoto, P., Wedjatmiko, Dharmadi dan Budiman, R.A.I. (1993). Pedoman Teknis Usaha Pembesaran Ikan Bandeng di Indonesia. Pusat Penelitian dan Pengembangan Perikanan, Jakarta. $93 \mathrm{hlm}$.

Kassila, J., Hasnaoui, M., Droussi, M., Loudiki, M. and Yahyaoui, A. (2001). Relation between phosphate and organic matter in fish-pond sediments of the Deroua fish farm (Béni-Mellal, Morocco): implications for pond management. Hydrobiologia, 450(1-3), 57-70.

Karthik, M., Suri, J., Saharan, N. and Biradar, R.S. (2005). Brackish water aquaculture site selection in Palghar Taluk, Thane District of Maharashtra, India, using the techniques of remote sensing and geographical information system. Aquacultural Engineering, 32, 285-302.

Liaw, W.K. (1969). Chemical and biological studies of fishponds and reservoirs in Taiwan. Rep. Fish Culture Res., Fish. Series, Chin. Am. Joint Commission on Rural Reconstruction 7:1-43.

Menon, R.G. ( 1973). Soil and Water Analysis: A Laboratory Manual for the Analysis of Soil and Water. Proyek Survey O.K.T. Sumatera Selatan, Palembang. $190 \mathrm{pp}$.

Montoya, R.A., Lawrence, A.L., Grant, W. E. and Velasco, M. (2002). Simulation of inorganic nitrogen dynamics and shrimp survival in an intensive shrimp culture system. Aquaculture Research, 33, 81-94.

Moore, J.W. (1991). Inorganic Contaminants of Surface Water. Springer-Verlag, New York. 334 pp.

Mustafa, A. (1998). Budi daya tambak di lahan gambut dan permasalahannya: studi kasus di Sulawesi Selatan. Jurnal Litbang Pertanian, XVII(3), 7382.

Mustafa, A. (2012). Kriteria kesesuaian lahan untuk berbagai komoditas di tambak. Media Akuakultur, 7(2), 108-118.

Mustafa, A., Hasnawi, Athirah, A., Sommeng, A. dan Ali, S.A. (2014). Karakteristik, kesesuaian, pengelolaan lahan untuk budidaya di tambak Kabupaten Pohuwato Provinsi Gorontalo. Jurnal Riset Akuakultur, 9(1), 135-149.

Mustafa, A., Rachmansyah dan Hanafi, A. (2007). Kelayakan lahan untuk budi daya perikanan pesisir. Dalam: Susilo, D.S.I., Wiadnyana, N.N., Wijayanti, E., Basmal, J., Asnawi, Supangat, A., Hanggono, A. dan Insan, I. (eds.), Prosiding
Simposium Nasional Hasil Riset Kelautan dan Perikanan Tahun 2007. Badan Riset Kelautan dan Perikanan, Jakarta. hlm. 141-159.

Mustafa, A. dan Ratnawati, E. (2005). Faktor pengelolaan yang berpengaruh terhadap produksi rumput laut (Gracilaria verrucosa) di tambak tanah sulfat masam (studi kasus di Kabupaten Luwu, Provinsi Sulawesi Selatan). Jurnal Penelitian Perikanan Indonesia, 11(7), 67-77.

Mustafa, A. dan Ratnawati, E. (2007). Faktor-faktor dominan yang mempengaruhi produktivitas tambak di Kabupaten Pinrang, Sulawesi Selatan. Jurnal Riset Akuakultur, 2(1), 117-133.

Mustafa, A. dan Ratnawati, E. (2013). Karakteristik dan pengaruh faktor lingkungan terhadap produksi ikan bandeng (Chanos chanos) di tambak tanah sulfat masam Kabupaten Konawe Selatan, Provinsi Sulawesi Tenggara. Jurnal Riset Akuakultur, 8(2), 325-338.

Mustafa, A. and Sammut, J. (2007). Effect of different remediation techniques and dosages of phosphorus fertilizer on soil quality and klekap production in acid sulfate soil-affected aquaculture ponds. Indonesian Aquaculture Journal, 2(2), 141-157.

Mustafa, A. and Sammut, J. (2010). Dominant factors effecting seaweed (Gracilaria verrucosa) production in acid sulfate soils-affected ponds of Luwu Regency, Indonesia. Indonesian Aquaculture Journal, 5(2), 147-162.

Mustafa, A., Sapo, I. Hasnawi dan Sammut, J. (2007). Hubungan antara faktor kondisi lingkungan dan produktivitas tambak untuk penajaman kriteria kelayakan lahan: 1. Kualitas air. Jurnal Riset Akuakultur, 2(3), 289-302.

Ndome, C.B., Udo, I.U., Akpan, I.I. and Udom, C. (2012). Effect of water quality and bottom soil properties on the diversity and abudance of macrobenthic in some tropical grow-out earthen fish ponds. Ecologia, 2(1), 12-22.

Parsons, T.R., Maita, Y. and Lalli, C.M. (1989). A Manual of Chemical and Biological Methods for Seawater Analysis. Pergamon Press, Oxford. 173 pp.

Poernomo, A. (1988). Pembuatan Tambak Udang di Indonesia. Seri Pengembangan No. 7. Balai Penelitian Perikanan Budidaya Pantai, Maros.40 hlm.

Ponnamperuma, F.N. (1972). The chemistry of submerged soils. Advances in Agronomy, 24, 2996.

Price, G. (2006). Australian Soil Fertility Manual.Third edition. CSIRO Publishing, Collingwood. 168 pp.

Ranoemihardjo, B.S., Kahar, A. and Lopez, J.V. (1979). Results of polyculture of milkfish and shrimp at the Karanganyar provincial demonstration ponds. Bulletin of Brackishwater 
Aquaculture Development Center, 5(1\&2), 334350.

Ratnawati, E., Hasnawi, dan Mustafa, A. (2014). Kesesuaian lahan aktual untuk budidaya udang windu di tambak Kabupaten Luwu Timur Provinsi Sulawesi Selatan. Jurnal Riset Akuakultur, 9(1), 151-164.

Reid, G.K. (1961). Ecology of Inland Waters and Estuaries. Van Nostrand Reinhold Co., New York. 375 pp.

Rutherford, R.D. and Choe, M.K. (1993). Statistical Model for Causal Analysis. John Wiley \& Sons, Inc., New York. 216 pp.

Salam, M.A., Ross, L.G. and Beveridge, C.M.M. (2003). A comparison of development opportunities for crab and shrimp aquaculture in southwestern Bangladesh, using GIS modeling. Aquaculture, 220, 477-494.

Sarwono, J. (2007). Analisis Jalur untuk Riset Bisnis dengan SPSS. Penerbit Andi, Yogyakarta. 321 hlm.

Sawyer, C.N. and McCarty, P.L. (1978). Chemistry for Environmental Engineering. Third edition. McGraw-Hill Book Company, New York. 532 pp.

Shang, Y.C. (1986). Pond production systems: stocking practices in pond fish culture. In: Lannan, J.E., Smitherman, R.O. and Tchobanoglous, G. (eds.), Principles and Practices of Pond Aquaculture. Oregon State University Press, Corvallis, Oregon. pp. 85-96.

Smayda, T. (1983). The phytoplankton of estuaries. In: Ketchum, B.H. (ed.), Estuaries and Enclosed Seas. Ecosystem of the World 26. Elsevier, Amsterdam. pp. 65-102.

Stevenson, F.J. (1982). Humus Chemistry: Genesis, Composition, Reactions. John Wiley \& Sons, New York. 433 pp.

Streiner, D.L. (2005). Finding our way: an introduction to path analysis.The Canadian Journal of Psychiatry, 50(2), 115-122.

Strickland, J.D.H. and Parsons, T.R. (1972). A Pactical Handbook of Seawater Analysis.Bulletin 167, Second edition.Fisheries Research Board of Canada, Ottawa.310 pp.

Sudradjat, A. dan Wedjatmiko. (2010). Budi Daya Udang di Sawah dan Tambak. Penebar Swadaya, Jakarta. 74 hlm.

Suliyanto. (2011). Ekonometrika Terapan: Teori \& Aplikasi dengan SPSS. Penerbit Andi, Yogyakarta. $311 \mathrm{hlm}$.

Supranto, J. (2004). Analisis Multivariat: Arti \& Interpretasi. Cetakan pertama. Rineka Cipta, Jakarta. $359 \mathrm{hlm}$.

Sutrisyani dan Rohani, S. (2009). Panduan Praktis Analisis Kualitas Air Payau. Cetakan kedua. Diedit: Rachmansyah, Atmomarsono, M. dan
Mustafa, A. Pusat Riset Perikanan Budidaya, Jakarta. $55 \mathrm{hlm}$.

Treece, G.D. ( 2000). Site selection. In: Stickney, R.R. (ed.), Encyclopedia of Aquaculture. John Wiley \& Sons, Inc., New York. pp. 869-879.

Wickins, J.F. (1984). The effect of reduced $\mathrm{pH}$ on carapace calcium, strontium and magnesium levels in rapidly growing prawns (Penaeus monodon Fabricius). Aquaculture, 41, 49-60.

Widarjono, A. (2010). Analisis Statistika Multivariat Terapan. Edisi pertama. UPP STIM YKPN, Yogyakarta. $358 \mathrm{hlm}$ 
